\section{Magdalena Popiel}

Uniwersytet Jagielloński

\title{
Bruno Schulz \\ i estetyka tworzenia
}

\section{Abstract \\ Bruno Schulz and the Aesthetics of Creation}

The article discusses the creative process as one of the main themes of Bruno Schulz's prose. The author considers two aspects of Schulz's creative aesthetics: the aesthetics of matter and the aesthetics of caprice. She describes the former, referring Schulz's thought to Rainer Maria Rilke, and the latter, considering it in the context of Gaston Bachelard's philosophy.

Stowa kluczowe: Bruno Schulz, Gaston Bachelard, estetyka tworzenia, estetyka materii, estetyka kaprysu

Keywords: Bruno Schulz, Gaston Bachelard, aesthetics of creation, aesthetics of matter, aesthetics of caprice 
Jak zacząć pisać o Brunonie Schulzu? Topika wstępu w schulzologii jest tak bogata, że sama w sobie stanowi wdzięczny temat dywagacji. Pytanie: ,jak zacząć?" oznacza oczywiście dylemat zgoła fundamentalny: jak się ulokować, jaką znaleźć pozycję, jak wygospodarować skrawek miejsca jeszcze dostatecznie nie zajętego, jak umościć się przez chwilę na piędzi ziemi zaoranej już wszerz i wzdłuż przez schulzologów?

Tak zacząwszy nie zaczynając, można by mój kłopot retoryczny potraktować szerzej. Czy w ogóle można jeszcze coś zaczynać? Pierwsze zdanie cyklu wykładów George'a Steinera z 1990 roku, opublikowanych jako Gramatyki tworzenia, brzmi: „Nie mamy już początków”. . Dowodzi on dalej, iż sztuka, która od zawsze żywiła się analogią do boskiego sprawstwa, wydaje się odchodzić w niepamięć. Tworzenie zostało wyparte przez „płodne wynajdywanie”, wynalazczość, jaką zrodziła nauka i technika. Steiner, ironizując, powiada, że już „artyści jaskiniowi z Altamiry czy Lascaux chcieli być kimś więcej niż tylko zręcznymi imitatorami »gotowca«, jakim jest świat, naśladowcami owego objet trouvé, jakim jest bizon"'2. Za drobną złośliwością wobec Marcela Duchampa idzie groźna diatryba przeciwko dadaizmowi i jego „trzem posępnym błaznom"', czyli temuż Duchampowi, Kurtowi Schwittersowi i Jeanowi Tinguely'emu. To właśnie tędy na początku XX wieku biegnie granica epok: nie przed awangardą czy po awangardzie, ale w poprzek niej. Oto jeszcze kilka nazwisk, za pomocą których Steiner wyznacza tę granicę:

[...] Picasso i Matisse należą do olimpijskiej przeszłości, niezależnie od swego artystycznego geniuszu. Z racji nieskrywanej troski o przyszłość, z racji marzenia o konsekracji w muzeum czy panteonie malarze ci są uczniami Giotta. Henry Moore podaje dłoń Andrei Pisano i Michałowi Aniołowi. U Strawińskiego czy Schoenberga duma, z jaką sięgają do dziedzictwa tradycji i aspirują do kanoniczności, jest równie wyraźna jak u „homeryckiego” Joyce’a czy Tomasza Manna utożsamiającego się z Goethem ${ }^{4}$.

Autor Gramatyk tworzenia zdaje się przekonywać, iż wymienieni tu artyści podchodzili z powagą do nieśmiertelności i w napięciu śledzili dramatyczne zapasy człowieka z Aniołem Ciemności, czyniąc z tych zmagań archetypiczny obraz tworzenia, obraz ożywający m.in. w dziełach Rembrandta czy Elegiach duinejskich Rainera Marii Rilkego.

Chciałabym wejść na chwilę w sam środek wyreżyserowanej przez Steinera sceny rozdarcia, jakie dokonało się zaledwie sto lat temu, i zastanowić się, po której stronie tego chiazmu kulturowego należałoby umieścić Schulza:

${ }^{1}$ G. Steiner, Gramatyki tworzenia. Na podstawie wygłoszonych w roku 1990 wykładów imienia Gifforda, przeł. J. Łoziński, Poznań 1991, s. 7.

2 Ibidem, s. 292.

3 Ibidem.

${ }^{4}$ Ibidem, s. 288. 
po stronie tworzenia i stwarzania czy po stronie wynalazczości, po stronie Picassa czy Duchampa? Nazwiska pisarzy, których wymienia Steiner, a więc np. Thomasa Manna i Rilkego, podpowiadają, gdzie powinniśmy ulokować autora Sklepów cynamonowych. A zatem po tamtej stronie?

Twórczość Schulza w całej swojej różnorodności wypowiedzi - opowiadań, eseistyki, recenzji czy wreszcie listów - wypełniona jest opowieściami o tworzeniu. Tajemnica tworzenia jest zasadniczą tkanką spuścizny tego pisarza; już Jerzy Ficowski w Regionach wielkiej herezji nazwał jego dzieło „traktatem o tworzeniu" i doskonale rozpoznał ten wyjątkowy casus Schulzowego creatio:

Kreacja pisarza jest zarazem swoją własną egzegezą, reguły Schulzowskiej rzeczywistości są jednocześnie prawami procesu twórczego; program artystyczny Schulza jest w metaforycznej transpozycji podzielony przez żywioły i moce Sklepów cynamonowych, a samookreślające sformułowania, dotyczące samego pisarza i jego twórczości, odniesione są do zjawisk opisywanych. Stąd sugestywna tożsamość, wspólnota pobudek i natury kreatora i kreacji, biologii żywej materii i twórczej działalności artysty. [...]

Z postaci Schulzowskich najczęściej ojciec jest wyrazicielem poglądów twórczych pisarza, a komentarze jego zachowań i wypowiedzi są także glosami do zasad własnego pisarstwa. Jest jakby znak równania między kodeksem natury a prawami kreatorstwa artystycznego, które ma za zadanie naśladować naturę, brać z niej przykład - jedynie w zakresie stwórczych działań, demiurgii, a więc nie w kopiowaniu jej urzeczywistnień, lecz we własnej, równie twórczej wynalazczości5.

Schulza zatem widziałabym jako jednego z najważniejszych bohaterów zaproponowanej przeze mnie historii tworzenia jako wariantu kulturowej historii literatury ${ }^{6}$. Artysta w naszej europejskiej kulturze był powołany nie tylko do działań twórczych, ale także do refleksji na temat procesu tworzenia. Świadectwa w postaci tekstów fikcjonalnych i dokumentów osobistych (listów, dzienników, esejów, notatek) budują niepowtarzalną sieć narracji tożsamościowych. Wskazując na tego rodzaju świadectwa, chcę podkreślić ich rangę i zasygnalizować możliwość ich wydzielenia jako odrębnego przedmiotu badań, tzn. oderwania ich zarówno od specjalistycznych sekwencji badawczych historii literatury, malarstwa, teatru czy muzyki, jak i od filozofii. Każda z tych dziedzin, a filozofia szczególnie, anektując obficie tego rodzaju świadectwa, podporządkowywała je własnym celom, zazwyczaj traktując te teksty instrumentalnie. Nadanie pisarzowi miana filozofa brzmiało w ustach literaturoznawców jak przyznanie mu najwyższej godności, przypięcie najwyższego odznaczenia w hierarchii zaszczytów, jakimi dysponuje Naczelny Interpretator. Tak bywało także z Schulzem filozofem, jak gdyby kategoria

5 J. Ficowski, Regiony wielkiej herezji i okolice. Bruno Schulz i jego mitologia, Sejny 2002, s. $88,89$.

${ }^{6}$ Por. M. Popiel, Historia historii tworzenia [w:] Projekt na daleka metę. Prace ofiarowane Ryszardowi Nyczowi, red. Z. Łapiński, A. Nasiłowska, Warszawa 2016, s. 69-79. 
artysty była tu fundamentalnie niewystarczająca i w sposób oczywisty niższa. Otóż mówiąc najkrócej, sądzę, że refleksję artystów nad tym, czym jest tworzenie, wyrastającą z jądra osobistego doświadczenia, można potraktować jako względnie autonomiczny obszar badań, wymagający odrębnych narzędzi i reguł, korzystający jednak z interdyscyplinarnych impulsów i metodologii.

Namysł nad tworzeniem jest źródłem, z którego wyrasta dzieło Schulza. Stwarzanie świata w każdym wymiarze: zarówno realności, jak i fantazji, materii i ducha, sfery profanum i sacrum, prozy i poezji życia, było pasją autora Sklepów cynamonowych. On sam i jego bohaterowie postrzegani są przede wszystkim jako podmioty kreacji ${ }^{7}$.

Witold Gombrowicz po lekturze Sanatorium pod klepsydra próbował rekonstruować proces twórczy Schulza poprzez takie wyobrażenia:

Wyobraźcie sobie, że zasiadacie do biurka, ażeby opisać jakieś zdarzenie w sposób normalny i realistyczny, aż tu naraz napada was myśl o niesłychanej fikcyjności waszego przedsięwzięcia, o mistyfikacji, jakiej dopuszczacie się na czytelniku. Przede wszystkim samo opisywanie urojonych zdarzeń, tak jakby one odbyły się naprawdę, nadawanie im pozorów realnego życia, skoro każdemu wiadomo, iż urodziły się one w waszej głowie, jest godną pożałowania fikcją i mistyfikacją. Po wtóre, czyż sens waszej pracy polega na tym właśnie, by czytelnik wyżywał się w anegdocie waszej opowieści, w przygodach waszych bohaterów - nie, przecież przygody są tylko pretekstem, za pomocą którego chcecie przekazać jakieś osobiste wzruszenia i doznania [...]. Idąc dalej po tej drodze, dochodzicie do myśli bardziej ogólnej i filozoficznej, że nie tylko urojone, lecz

${ }^{7}$ Liczni interpretatorzy Schulza wskazywali obecność w jego tekstach kilku alternatywnych nurtów refleksji nad tworzeniem. Jerzy Jarzębski w znakomitym szkicu Dramat tworzenia przekonuje, iż ów dramat tworzenia, który z samej swej istoty musi być wielowarstwowy i zarazem historyczny, zawiera w sobie ,zarówno historię prywatną samego twórcy, jak historię świata, w którym działał [...]" (J. Jarzębski, Dramat tworzenia [w:] idem, Schulzowskie miejsca i znaki, Gdańsk 2016, s. 78). Michał Paweł Markowski wyróżnia pięć modeli, z których Schulz swobodnie korzysta: „Pierwsza z nich [filozofia twórczości - dop. M.P.] powiada, że twórczość to komentowanie tekstu nieświadomości. Druga, że jest to odpowiedź na wezwanie Boga. Trzecia, że jest to przeprowadzanie świata z ciemności w blask. Czwarta, że jest to wyzwalanie zahamowanej w swym wzroście materii. Piąta wreszcie, że jest to podpatrywanie procesu, za pomocą którego nadrzeczywistość próbuje się wcielić w istniejące formy, czyli od-twarzanie ontologicznej zasady świata. [...] Dwie rzeczy można jednak powiedzieć o nim [Schulzu - dop. M.P.] z całą pewnością. Po pierwsze każdy z tych modeli wspiera jego metafizyczną pasję i kiedy Schulz powiada w Mityzacji rzeczywistości, że »mowa jest metafizycznym organem człowieka« [...], to należy to tak rozumieć, że mowa ma w sobie moc stanowienia rzeczywistości. Po drugie zaś, że twórczość Schulza nieustannie oscyluje między dwoma porządkami: Nocą i Dniem, Ciemnością i Blaskiem, Nieświadomością i Rozumem” (M.P. Markowski, Polska literatura nowoczesna. Leśmian, Schulz, Witkacy, Kraków 2007, s. 189 [podkr. - M.P.M.]). 
nawet rzeczywiste zdarzenia są właściwie pozorem i pretekstem, że nawet prawdziwi, żywi ludzie są tylko przypadkowym kształtem, maską, poza którą czai się ciemny i anonimowy żywioł ${ }^{8}$.

W jego ujęciu to, co najistotniejsze w tworzeniu, zaczyna się momencie, gdy „napada na was myśl” samozwrotna, autopoietyczna, właściwy impuls twórczy jest kaprysem myśli, gwałtownym zwrotem ku „herezji i anarchii”. Bunt wywieszający na sztandarach hasło totalnej mistyfikacji lokuje się w przestrzeni między tym, co nieświadome, a tym, co racjonalne. $\mathrm{W}$ takim trybie istnienia „,realna” i „fikcyjna” rzeczywistość staje się „tylko przypadkowym kształtem". Ale zanurzenie w odmętach chaosu daje nadzieję na odsłonięcie jakiegoś sensu. Cały ten proces dla Gombrowicza był światem Wielkiej Manipulacji, a dla Schulza - Wielkim Laboratorium Materii.

Proponuję, by podążyć za wątkiem szczególnej tożsamości wyobrażenia materii i procesu tworzenia w dziele Schulza. Interesować mnie zatem będą dwa aspekty estetyk i tworzenia Schulza wynikające z dwojakiej kontekstualizacji. Pierwszym będzie mitologia tworzenia, która wyrosła z refleksji nad tym rodzajem sztuki, który jest najbardziej związany z materialnością artefaktu, czyli rzeźbą. Drugi będzie dotyczył trybu poruszania się podmiotu twórczego we wspólnej przestrzeni poznania i pragnienia. Punktem odniesienia w pierwszym wypadku będzie Rainer Maria Rilke, a w drugim - filozof o temperamencie artysty, czyli Gaston Bachelard. Pierwszy z nich pozwoli wejrzeć w estetykę materii, drugi w estetykę kaprysu.

\section{Estetyka materii}

Artysta szuka partnera do rozmowy o tworzeniu często poza tymi szlakami powiązań, które wyznacza używane przez niego medium. Wspólnoty w tym zakresie nie determinuje język czy obraz, ale właśnie struktura doświadczenia tworzenia. A także biografia - egzystencja wyznaczona przez podobne „dymensje”, jak powiedziałby Schulz ${ }^{9}$. Przyjmując taki punkt widzenia, warto się przyjrzeć fascynacji autora Sklepów Rainerem Marią Rilkem.

Debiut Schulza przypada siedem lat po śmierci Rilkego (poeta zmarł w 1926 roku). Autor Sklepów cynamonowych często zwierza się w listach, jak wielkie wrażenie zrobiły na nim czytane w oryginale tomy poezji: Das Stun-

${ }^{8}$ W. Gombrowicz, Twórczość Brunona Schulza [w:] idem, Varia, Paryż 1973, s. 204. Uwspółcześniono interpunkcję w cytacie.

${ }_{9}$ Por. znakomity tekst J. Ficowskiego $W$ poszukiwaniu partnera kongenialnego [w:] Czytanie Schulza. Materiaty międzynarodowej sesji naukowej „Bruno Schulz - w stulecie urodzin i w pięćdziesięciolecie śmierci”, red. J. Jarzębski, Kraków 1994, s. 18-32. 
denbuch (Księga godzin), Neue Gedichte (Nowe wiersze), Duineser Elegien (Elegie duinejskie) oraz powieść Die Aufzeichnungen des Malte Laurids Brigge (Malte: Pamiętniki Malte-Lauridsa Brigge) (Artur Sandauer wspomina o całej części biblioteki niemieckojęzycznej klasyki z Mannem, Franzem Kafką i właśnie Rilkem na czele) ${ }^{10}$. W liście do Rudolfa Ottenbreita Schulz pisze, że czytając Rilkego, ,należałoby właściwie przejść wszystkie jego dzieła razem" "11. Skoro zatem najpewniej znał tę twórczość w całości, to należy uznać, że nieobce mu były także dwa szkice Rilkego poświęcone Auguste’owi Rodinowi, na które chcę tutaj zwrócić szczególną uwagę (zostały one przetłumaczone i wydane przez Witolda Hulewicza w 1923 roku $^{12}$ ).

Pozostawię na uboczu wielokrotnie wskazywaną i analizowaną zbieżność toposów prozy Schulza i poezji Rilkego, takich jak: dzieciństwo, figura ojca, lalki czy miasto ${ }^{13}$. Interesuje mnie tutaj nurt autopoietyczny i egzystencjalny w tekstach obu artystów, koncentrujący się na samej istocie doświadczenia człowieka tworzącego.

Dla Rilkego źródłem fascynacji artystycznych, inspiracji intelektualnych, a także wzorców egzystencjalnych było dwóch artystów niepoetów: Paul Cézanne, którego nie zdążył poznać osobiście, ale za którego obrazami zjeździł pół Europy, i właśnie Rodin, którego był sekretarzem i wielkim admiratorem (wspólnie zresztą z żoną Clarą Westhoff, rzeźbiarką i uczennicą twórcy Myśliciela).

Co Schulz mógł wyczytać interesującego w szkicach Rilkego o Rodinie, jak wpłynęły one na jego wyobraźnię, wrażliwość i poglądy?

Zarówno wędrujący po Europie niemiecki poeta, jak i prowincjonalny nauczyciel z Drohobycza wsłuchiwali się uważnie w to, co niewyraźnie i niejasno wypowiadał wiek XX. Obaj szukali języka, w jakim mogliby artykułować

${ }_{10}$ Por. A. Sandauer, Rilke, „Polityka” 1982, nr 33. W listach do Stefana Szumana pada słynny epitet „boski Rilke” i po nim lapidarna charakterystyka jego twórczości: „To jest bardzo cichy, zamknięty w sobie świat, trzeba odejść bardzo daleko od zgiełku i zejść bardzo głęboko, ażeby usłyszeć tę poezję, Narcysyzm, samotność, zamknięcie w szklanej bani” (list z 24 VII 1932; cyt. za: B. Schulz, Księga listów, zebrał i przygot. do druku J. Ficowski, uzup. S. Danecki, Gdańsk 2016, s. 36).

Józefina Szelińska tak wspominała po latach Schulza: „Przynosił Rilkego, czytał niektóre jego wiersze niezapomnianym, sugestywnym, tajemniczo dalekim od wszelkiego recytatorstwa głosem, jakby to on sam tworzył te wiersze Rilkego" (cyt. za: J. Ficowski, Wprowadzenie [do:] B. Schulz, Księga listów, s. 19-20).

${ }^{11}$ I dodawał intrygującą opinię: „Zdaje mi się, że mówił mi [Jerzy - dop. M.P.] Janisch, że Pan uwielbia Rilkego. Otóż na ten temat jest strasznie dużo do pomówienia. [...] Nie chodzi o samego Rilkego, ale o sprawy - że tak powiem wspólne, o sprawy między nim a nami, o wszystko to, co on zaniedbał napisać, a co my musimy uzupełnić" (B. Schulz, Księga listów, s. 63).

${ }_{12}$ R.M. Rilke, Auguste Rodin, przeł. Olwid [W. Hulewicz], Warszawa-Kraków 1923.

${ }_{13}$ Por. m.in. interesujące prace K. Kuczyńskiej-Koschany (Rilke poetów polskich, Wrocław 2004) i A. Czabanowskiej-Wróbel (Obraz Króla Olch w prozie Schulza [w:] Czytanie Schulza...). 
głębokie zaniepokojenie i zdziwienie światem. W tych pierwszych dekadach XX wieku wydawało się, że kosmos otwarł przed człowiekiem otchłanie tajemnic. Dla sztuki i nauki, między którymi nie istniały ostre granice, ówczesny świat ruszył z posad. Rilkego opowieść o Rodinie to historia kopernikańskiego przewrotu polegającego na odwróceniu porządku myślenia o formowaniu materii, o narodzinach kształtu z eksplozji światła, linii, płaszczyzn. Odmiennie niż w nowożytnym dyskursie utożsamiającym rzeźbę ze światem zatrzymanym, spetryfikowanym w sensie metaforycznym i dosłownym, Rilke dostrzega w dziełach Rodina dynamikę wiecznego ruchu.

Wydaje się, że właśnie od niemieckiego poety snującego opowieść o zagadkach tożsamości artysty rzeźbiarza pochodzi Schulzowski impuls refleksji nad procesem tworzenia. Byłby to argument na rzecz tezy Ficowskiego, który wskazuje na Rilkego jako patrona wyobraźni autora Sklepów cynamonowych ${ }^{14}$.

Obaj z pewnością, jak powiadał Rilke, czuli w sobie „smak stworzenia”" Łączyło ich przekonanie, że ponawiane pytanie o sens i strukturę creatio pozwoli współczesnemu człowiekowi chociaż częściowo okiełznać atakującą z wszystkich stron niezrozumiałą nowoczesność. Rilke w słynnym liście do Hulewicza pisał o szczególnym obowiązku ciążącym na świadkach epoki: „musimy próbować osiągnąc największą możliwą świadomość naszego istnienia”" ${ }^{16}$. W tym też Schulz postrzegał geniusz Rilkego: „Istnienie jego książek [...] jest gwarancją, że zagmatwane, głuche masy niesformułowanego w nas mogą wydostać się jeszcze na powierzchnię cudownie wydestylowane" ${ }^{17}$.

Europejska tradycja refleksji nad sztuką rzeźbiarską odnawia najbardziej pierwotne i podstawowe znaczenie materii. Rzeźbiarz zmagający się z głazem, trzymający w uścisku kawałek gliny, sytuował się najbliżej owego archetypicznego Jakuba walczącego z Aniołem. Schulz, architekt światów, republik i miast, a także rzeźbiarz ich mieszkańców ${ }^{18}$, wszystko to, co zmysłowe i duchowe, psychiczne i cielesne, wywodził z jednej żyjącej swoim życiem materii. Materia jest zatem dla niego nie tylko bramą prowadzącą w bezmiar możliwości, ale także otwarciem i przyzwoleniem na każdy kaprys formy. Jest

${ }_{14}$ Por. B. Schulz, Z listów odnalezionych, wstęp i oprac. J. Ficowski, Warszawa 1993, s. 75.

${ }_{15}$ R.M. Rilke, Przeżycie [w:] idem, Druga strona natury. Eseje, listy i pisma o sztuce, przeł. i oprac. T. Ososiński, Warszawa 2010, s. 142.

${ }^{16}$ Idem, Listy do Witolda Hulewicza [w:] idem, Druga strona natury..., s. 170.

${ }^{17}$ Cyt. za: J. Ficowski, Regiony wielkiej herezji..., s. 92.

${ }_{18}$ A także siebie jako twórcy. Analiza rzeźbiarskiej wyobraźni Schulza jest jeszcze tematem, który czeka na opracowanie. Z wielu obrazów, które odnaleźć można w jego tekstach, szczególnie poruszający jest ten z wyobrażeniem siebie jako nieszczęsnego Atlasa. Można podejrzewać, że trafił on do imaginarium Schulza właśnie poprzez rzeźby przedstawiające te postać bądź do niej nawiązujące, co w sztuce przełomu XIX i XX wieku nie należało do rzadkości. Zob. jego list do Tadeusza Brezy z 21 czerwca 1934 roku (B. Schulz, Księga listów, s. 51). 
koniecznością determinującą wszelkie tworzenie, sferą pierwszą i elementarną, która inicjuje rytuał kreacji zanurzony zarówno w materialności kamienia, jak i w cielesności rzeźbiarza trzymającego dłuto.

Jaka konkretnie była Rilkeańska lektura dzieł Rodina i w których momentach wydaje się ona szczególnie bliska Schulzowi? Sporządzę krótką listę takich spotkań myśli i wyobraźni.

1. Związek między naturą a działaniami artysty nie jest, według Rilkego i Schulza, ani mimetyczny, ani metaforyczny. Jedność ontologiczna wszelkich tworów stanowi zasadniczą przesłankę tworzenia, akt twórczy jest postrzegany jako element naturalnej proliferacji, rozrastania się materii kosmosu.

Traktat o manekinach, albo Wtóra Księga Rodzaju rozpoczyna się od wykładu „ogólnych zasad kosmogonii”'19:

Materii dana jest nieskończona płodność, niewyczerpana moc życiowa i zarazem uwodna siła pokusy, która nas nęci do formowania. W głębi materii kształtują się niewyraźne uśmiechy, zawiązują się napięcia, zgęszczają się próby kształtów. Cała materia faluje od nieskończonych możliwości, które przez nią przechodzą mdłymi dreszczami. Czekając na ożywcze tchnienie ducha, przelewa się ona w sobie bez końca, kusi tysiącem słodkich okrąglizn i miękkości, które z siebie w ślepych rojeniach wymajacza. [...]

Mój ojciec był niewyczerpany w gloryfikacji tego przedziwnego elementu, jakim była materia [...]. Skala tych form jest nieskończona, a odcienie i niuanse niewyczerpane ${ }^{20}$.

W Republice marzeń Schulz zapewni, że „[...] żadne marzenie, choćby nie wiedzieć jak absurdalne i niedorzeczne, nie marnuje się w wszechświecie"21. Rilke z podobnej koncepcji materii wyprowadza istotny wniosek: „Powołaniem jego [Rodina - dop. M.P.] było pracować tak, jak pracuje przyroda, nie tak, jak ludzie"22. Kilka lat później tę myśl dokładnie powtórzy Pablo Picasso: „nie naśladuję natury, ja pracuję jak ona"23.

2. Rilke i Schulz podzielali przekonanie, iż działania artysty zmierzają do odnowienia wspólnej sfery egzystencjalnej: status rzeźby jako przedmiotu, według Rilkego, odsyła do doświadczenia dzieciństwa. Uważał on, że każdy człowiek odkrywał wówczas rzeczy, którym nadawał wyjątkową

19 B. Schulz, Traktat o manekinach albo Wtóra Księga Rodzaju [w:] idem, Opowiadania. Wybór esejów i listów, oprac. J. Jarzębski, Wrocław 1989, s. 34.

${ }^{20}$ Ibidem, s. 33-34.

${ }^{21}$ B. Schulz, Republika marzeń [w:] idem, Opowiadania..., s. 331.

22 R.M. Rilke, Auguste Rodin, przeł. W. Wirpsza, Kraków 1963, s. 146.

${ }^{23}$ Cyt. za: F. Gilot, C. Lake, Żyć z Picassem, przeł. M. Iwańska-Feliksowa, Warszawa 1997, s. 53. 
wartość emocjonalną; wyobraźnia i uczucia dziecka powielały akt stworzenia, przypisując przedmiotowi wszystkie możliwe role. Oto Rilkeańska legitymizacja artefaktu:

Ów drobny, zapomniany przedmiot [...]. To „coś”, mimo iż tak bezwartościowe, przygotowywało wasze stosunki ze światem, wprowadziło was w dzieje i pomiędzy ludzi i więcej jeszcze: dzięki niemu, dzięki jego istnieniu, dzięki byle jakiemu jego wyglądowi, dzięki temu, że połamał się w końcu czy wyśliznął w zagadkowy sposób, przeżyliście wszystko co ludzkie głęboko, aż po samą śmierć.

[...] i teraz jeszcze potrzebujecie przedmiotów, które podobnie jak przedmioty dzieciństwa, czekają na wasze zaufanie, na miłość i oddanie wasze ${ }^{24}$.

3. Obaj artyści byli zafascynowani demiurgią ułomną, ,,heretycką”, dla której najlepszym obrazem była materia ciała. Rilke zwracał uwagę na Rodinowskiego Człowieka ze złamanym nosem i liczne korpusy bez rąk. Genezę tego artystycznego konceptu thumaczył teatralnym eksperymentem:

Rodin uważał je [ramiona - dop. M.P.] [...] za zbyt łatwe rozwiązanie swego zadania, za coś, co nie przynależy do ciała, które pragnęło otoczyć się sobą samym, bez obcej pomocy. Można tu pomyśleć o [Eleonorze - dop. M.P.] Duse, która w jednym z dramatów D'Annunzia, boleśnie opuszczona, usiłuje obejmować bez użycia ramion i trzymać bez rąk. Scena ta, w której ciało jej nauczyło się pieszczoty znacznie przekraczającej jego granice, należy do niezapomnianych cech jej gry. Sprawiała bowiem wrażenie, że ręce są nadmiarem, ozdobą, właściwością ludzi bogatych i nieumiarkowanych, rzeczą, którą można od siebie odrzucić, aby stać się całkiem ubogim. I nie sprawiała ona w tej chwili wrażenia kogoś, kto utracił coś ważnego; raczej kogoś, kto oddaje własny kubek, aby pić wprost z potoku, człowieka, który jest nagi i odrobinę jeszcze w głębokim swym obnażeniu nieporadny ${ }^{25}$.

Estetycznej motywacji „wtórej demiurgii” ${ }^{26}$ Rilke poszukuje nie w sile ekspresji, ale w szczególnej relacji formy i materii. W rzeźbie harmonijne ciało jest tym, czym frazes w ludzkiej mowie; w języku ciała u Rodina dominuje autoteliczność, wynajdywanie wewnętrznych reguł, np. efektu zderzenia powierzchni i linii. Źródłem tych efektów jest ruch, a u jego początków i na jego przedłużeniu pojawia się gest.

24 R.M. Rilke, Auguste Rodin, przeł. W. Wirpsza, s. 116.

${ }^{25}$ Ibidem, s. 44-45.

${ }^{26}$ B. Schulz, Traktat o manekinach..., s. 35. 
4. W centrum ,świata według naszego gustu”27, jak powiada Schulz, znajduje się właśnie gest. Rilke wyjaśnia tę uprzywilejowaną rolę gestu w dwojaki sposób: gest ma wymiar mityczny, jest w mowie ciała rodzajem prasłowa, bruzdą, wyżłobieniem w powierzchni, które pozwala spojrzeć w głąb czasu.

[...] wszystko, co nazywamy duchem i duszą, i miłością: czyż nie jest drobną zaledwie zmianą na niewielkiej powierzchni bliskiej nam twarzy? [...]

[...] wszystko to przecież w pewnym momencie było jedynie ściągnięciem warg, uniesieniem brwi, cieniami na czołach: i owa rysa wokół ust, owa linia nad powiekami, ów mrok na jakiejś twarzy - istniały może już niegdyś zupełnie w ten sam sposób: jako wzór na sierści zwierzęcej, jako bruzda w skale, jako wgłębienie w jakimś owocu $[\ldots]^{28}$.

Poza tym gest jest znakiem rozpoznawczym nowoczesności w wymiarze antropologicznym i estetycznym. Rilke opisuje ,nowe gesty” charakteryzujące współczesnego człowieka, tak jak gesty utrwalone przez Dantego w Boskiej komedii dawały wyobrażenie o człowieku średniowiecza. Dzisiejsze ruchy w przeciwieństwie do dawnych są:

[...] niecierpliwe, nerwowe, szybkie i spieszne. [...] zarazem powściągliwsze. Nie posiadają one już [...] prostoty [...]. Nie przypominają ruchów, które zachowały się $\mathrm{w}$ dawnych rzeźbach, gestów, gdzie ważny był jedynie punkt wyjściowy i końcowy. Pomiędzy tymi dwoma prostymi momentami wsunęły się niezliczone przejścia i okazało się, iż życie współczesnego człowieka schodziło właśnie na tych stanach pośrednich - zarówno jego działanie, jak i niemożność działania ${ }^{29}$.

W taki właśnie sposób przedstawia ruch ręki Myśliciela czy nogę Idącego. $\mathrm{O}$ pierwotnej, a zarazem organizującej roli gestu w estetyce tworzenia Schulz mówi m.in. w Traktacie o manekinach:

Często dla jednego gestu, dla jednego słowa podejmiemy się trudu powołania ich do życia na tę jedną chwilę. [...] Naszą ambicję pokładać będziemy w tej dumnej dewizie: dla każdego gestu inny aktor. Do obsługi każdego słowa, każdego czynu, powołamy do życia osobnego człowieka. Taki jest nasz smak, to będzie świat wedhug naszego gustu ${ }^{30}$.

${ }^{27}$ Ibidem. Duse zagrała co najmniej trzy główne role kobiece w dramatach D'Annunzia napisanych na przełomie wieków XIX i XX. Chodzi o sztuki: La Gioconda, La città morta i Francesca da Rimini (ta ostatnia jest jej także dedykowana). Zob. F. Winwar, Wingless Victory: A Biography of Gabriele D'Annunzio and Eleonora Duse, New York 1956, s. $182-198$.

${ }^{28}$ R.M. Rilke, Auguste Rodin, przeł. W. Wirpsza, s. 121-123.

${ }^{29}$ Ibidem, s. 57-58.

${ }_{30}$ B. Schulz, Traktat o manekinach..., s. 35. 


\section{Creatio jako kaprys}

Opisywane przez obydwu pisarzy akty kreacji mają znamiona stwarzania ex nihilo. Historia potrójnych narodzin dzieła, artysty i świata tworzy ścisły splot trzech wątków narracji. Te opowieści zwracają się do początków jako głównego źródła sensu z całą świadomością tego, jak bardzo jest on zanurzony w niepewnej aurze mitu. Mityzacja rzeczywistości $i^{31}$ jest pierwotną Księga Genesis Schulza; opowieść o grawitacji słowa ciążącego ku sensowi staje się fundamentalną kosmogonią artysty. A na przedłużeniu słowa umieszcza on obraz i symbole matematyczne. „Sens jest [...] daną absolutną”, ale gdzie jest i czym jest - „niepodobna określić” ${ }^{32}$. Poddanie się siłom grawitacji wydaje się dla Schulza tyleż oczywiste, ile absurdalne, podobnie jak prawa kosmosu wypełnionego rzeczami, „które się całkiem, do końca, nie mogą zdarzyć" 33 . Pytania stawiane takiej rzeczywistości przypominają te, które zadawali dwudziestowieczni astrofizycy zastanawiający się, co działo się w umyśle nieistniejącego Boga godzinę przed Wielkim Wybuchem. Trajektorie, jakimi podążają myśli poetów, dzieci i wizjonerów nauki, przecinają się w wielu punktach. Zarówno Schulz, jak i Rilke, choć zapewne w różnym stopniu, odczuwają apokaliptyczny lęk przed Niestwarzającym Stwórcą. Pomiędzy wizerunkiem Boga Doskonałego Demiurga a wizerunkiem Stwórcy Niestwarzającego pojawia się jednak inny jeszcze koncept, który można odnaleźć w Schulzowskiej wyobraźni. To kapryśny Bóg objawiający się w Wiośnie:

Zrozumiałem cię, o Boże. To były wszystko wybiegi Twojego bogactwa, to były pierwsze lepsze słowa, które Ci się nawinęły. Sięgnąłeś ręką do kieszeni i pokazałeś mi, jak garść guzików, rojące się w Tobie możliwości. Tobie nie chodziło o ścisłość, mówiłeś, co Ci ślina na język przyniosła. Mogłeś tak samo powiedzieć: Panfibras i Haleliwa, i powietrze załopotałoby wśród palm papugami do potęgi, a niebo, jak ogromna, stokrotna, szafirowa róża, rozdmuchana do dna - ukazałoby olśniewające sedno - oko Twoje pawiookie, urzęsione i przeraźliwe [...]. Ty chciałeś mnie olśnić, o Boże, pochwalić się, skokietować mnie, bo i Ty masz chwile próżności, kiedy się sam sobą zachwycasz. O jakże kocham te chwile! ${ }^{34}$

Kolejny, dziesiąty, rozdział Wiosny, przyniesie fascynujący portret prestidigitatora, który rychło okaże się bohaterem Księgi Stworzenia:

\footnotetext{
${ }_{31}$ Zob. idem, Mityzacja rzeczywistości [w:] idem, Opowiadania..., s. 365-368.

32 Ibidem, s. 367.

${ }^{33}$ B. Schulz, Księga [w:] idem, Opowiadania ..., s. 119.

${ }^{34}$ Idem, Wiosna [w:] idem, Opowiadania..., s. 145-146.
} 
[...] w końcu stawało się jasne, jak na dłoni, że go to nic nie kosztuje, że czerpie tę obfitość nie z własnych zasobów, że mu po prostu otworzyły się źródła nadziemskie, nie podług ludzkich miar i rachub. Ktoś wówczas, predestynowany do recepcji głębszego sensu tej demonstracji, odchodził do domu zamyślony i olśniony wewnętrznie, przeniknięty do głębi prawdą, która weń weszła: Bóg jest nieprzeliczony $[\ldots]^{35}$.

Kim zatem może być artysta? Magiem i herezjarchą - tę kontaminację ról w opisał już znakomicie Krzysztof Stala:

Literatura polska poruszała się i porusza w pewnej określonej przestrzeni, wyznaczanej przez figury funkcji artysty. Funkcje Nauczyciela, Proroka, Szydercy, Błazna, Kapłana stanowią jakiś ,,żelazny paradygmat”, poza który trudno się przebić, poza którym recepcja twórczości staje się utrudniona, spychana na marginesy dziwactw i peryferie nienaturalności. Taka była i jest, w pewnej mierze, sytuacja twórczości Schulza i jej recepcji.

Wydaje się, że zarówno bogactwo, jak i „oboczność” Brunona Schulza polegają na tym, że tworzy on lub próbuje tworzyć w swoim dziele dwie zupełnie inne opcje wobec rzeczywistości, nowe figury twórcy, dotychczas słabo obecne lub nieobecne w ogóle w polskiej tradycji literackiej. To figury maga i herezjarchy, których poetyckie ekwiwalenty znajdujemy we wszystkich warstwach tej twórczości, wyrażone wprost i poprzez specyficzny rodzaj stosunku do rzeczywistości, relacji sztuka-świat.

Tworzenie magicznej rzeczywistości - to „dosłowne” budowanie świata ze słów; magicznych zaklęć i horoskopów, to kreacja świata, w którym „rzeczywistość przybiera pewne kształty tylko dla pozoru, dla żartu, dla zabawy" [...]. To zabawa w magię, igranie rzeczywistością, która jak za dotknięciem czarodziejskiej różdżki zmienia kolory, zrzuca przebrania, żongluje sensem, wypuszcza coraz to inne wyglądy, które rozpadają się, giną i powstają na nowo. Magiczne słowo powołuje do istnienia i dokonuje deziluzji, obnaża; w tej grze wszystko jest możliwe, słowa i rzeczy odrywają się od swoich korzeni, szukają poetyckiej wolności, wcielają się w nowe realności - „ktoś jest człowiekiem, a ktoś karakonem, ale ten kształt nie sięga istoty, jest tylko rolą na chwilę przyjętą, tylko naskórkiem, który za chwilę zostanie zrzucony" $[\ldots]^{36}$.

35 Ibidem, s. 147-148.

${ }^{36}$ K. Stala, Architektura Schulzowskiej wyobraźni [w:] Czytanie Schulza ..., s. 218-219 (oba cytaty pochodzą z niedatowanego listu Schulza do Witkacego, zob. B. Schulz, Księga listów, s. 105). Wątek ten Stala rozwija także w swojej książce Na marginesach rzeczywistości. O paradoksach przedstawiania w twórczości Brunona Schulza, Warszawa 1995. 


\section{Groteskowa estetyka kaprysu}

Wydaje się, że Rilke oglądający świat przez pryzmat rzeźb Rodina mógł przypominać Schulzowi mądrego starca z Wędrówek sceptyka, a zatem człowieka, który nic „nie wiedział jeszcze o zdradliwości nauk przyrodniczych, żywił prostoduszną i naiwną wiarę w atomy i materię" ${ }^{37}$. To demiurg czasów, w których „trzon dogmatów życiowych był jeszcze nienaruszony” a kosmos „,był wymierzony w kategoriach myśli ludzkiej”38. Ale to tylko pół prawdy. Rilke zmarł w 1926 roku i nie był jak Schulz pasjonatem odkryć naukowych, nie wiedział tego wszystkiego, co już dziesięć lat później geniuszowi z Drohobycza pozwoli napisać, że:

[...] od czasów dobrego starca przeszedł świat przez wiele sit o ciasnych okach, w których zostawiał stopniowo swą konsystencję. Freudyzm i psychoanaliza, teoria względności i mikrofizyka, kwanty i geometria nieeuklidesowa. To, co przesączyło się przez te sita, to już był świat niepodobny do świata, fauna śluzowata i bezforemna, plankton o konturach płynnych i falujących ${ }^{39}$.

Jednak obaj, i Rilke, i Schulz, byli wyposażeni we wrażliwość pozwalającą wsłuchiwać się w świat $\mathrm{z}$ natężeniem najczulszej membrany i dysponowali wyobraźnią porównywalną z fantazjami fizyków i astronomów. Dlatego horyzont doświadczeń twórczych Rilkego tak doskonale współbrzmi z nowatorskimi projektami naukowymi Georga Simmela, prekursora nowoczesnej socjologii, a świat Schulza pełen jest proroczych intuicji.

Dystans między sztuką a nauką w latach trzydziestych, w czasach intensywnej twórczości Schulza, na przemian wydłużał się i zmniejszał. Jednakże im bardziej ziemia i kosmos traciły swoje, wydawało się, raz na zawsze określone parametry, a każdy rok wielkich odkryć otwierał drogę do kolejnych pytań, sztuka i nauka spotkały się w dwoistości, o której można by powiedzieć słowami Paula Valéry'ego: „Czasem myślę, czasem jestem”" . Jan Błoński posłużył się tą frazą jako mottem w swojej przedmowie do polskiego wyboru pism Gastona Bachelarda ${ }^{41}$. W latach trzydziestych, kiedy ukazały się Le nouvel esprit scientifique (Nowy umyst naukowy, 1934) i La formation de l'esprit scientifique (Ksztaltowanie się umystu naukowego, 1938, wyd. pol. 2002), Bachelard był przede wszystkim filozofem nauki, który zdecydowanie więcej widział

${ }^{37}$ B. Schulz, Wędrówki sceptyka [w:] idem, Opowiadania..., s. 408.

38 Ibidem.

39 Ibidem, s. 408-409.

40 „Parfois je pense; et parfois, je suis”. P. Valéry, Choses tues [w:] idem, Oeuvres, édition par J. Hytier, vol. 2, Paris 1960, s. 500 [podkr. - P.V.].

${ }^{41}$ G. Bachelard, Wyobraźnia poetycka. Wybór pism, wyb. H. Chudak, przeł. H. Chudak, A. Tatarkiewicz, przedm. J. Błoński, Warszawa 1975. 
różnic niż podobieństw między nauką i poezją. Podzielając postawę krytyczną wobec wiedzy opartej na geometrii Euklidesa, teorii Isaaca Newtona i filozofii Kartezjusza, był przekonany, że „Nic nie jest oczywiste samo z siebie, nic nie jest dane. Wszystko jest skonstruowane"42. Jednakże w 1933 roku, a więc roku debiutu Schulza, Bachelard, opublikował szkic Le monde comme caprice et miniature (Świat jako kaprys i miniatura) ${ }^{43}$ będący intrygującym dotknięciem czułego punktu wyobraźni i poglądów Schulza.

Bachelard sformułował w nim własną koncepcję powstawania obrazów w poznaniu zmysłowym. Proces poznania nie jest ani obiektywny, ani ciągły i nie daje satysfakcji pewności. Wraz ze skierowaniem zainteresowania w stronę wyobraźni myśliciel zaczął w swych rozważaniach uwzględniać istotny komponent poznawczy: emocje. Uważał on np., że „,...] psychika jest ożywiana prawdziwym głodem obrazów" ${ }^{4}$. Bez uwzględnienia tych pragnień nie da się opisać marzenia, obraz jest bowiem „mediacją między nami a naszym chceniem" 45 .

Kilka lat temu, przypominając ten ciekawy tekst Bachelarda, Magdalena Popiel zwróciła uwagę, że:

Kapryśne spojrzenie kreujące migotliwy, ruchomy, zmienny obraz ma swoje podstawy w dwóch źródłach: bezpośrednim zakorzenieniu wizualizacji w materii ciała oraz sferze pragnień. Kaprys to prymarna forma intuicji podmiotu w jej wymiarze taumaturgicznej, cudotwórczej, magicznej, to wola wizualizacji w cudowny sposób zawieszająca inercję przedmiotów: „to władcza siła, która zabawia się, kręcąc kalejdoskopem odległych miniatur [...]. Długo przed człowiekiem wcielającym typ Homo faber, to Puer lusor posiadł świat dzięki swej zabawce" ${ }^{\text {"46 }}$.

Schulzowski bohater Wędrówek sceptyka wydaje się groteskowym wariantem alegorycznego Kaprysu. Jest cieniem Jakuba z opowiadań - metafizycznego sztukmistrza, magika, magnetyzera „uwodzącego [rzeczy - dop. M.P.] swym niebezpiecznym czarem" ${ }^{47}$. W szkicu Schulza ta kaprysowa analogia staje się wizualnie jeszcze bardziej wyrazista: dziecięcy kalejdoskop, pałeczka magika zmienia się w:

42 Idem, Ksztaltowanie się umystu naukowego. Przyczynek do psychoanalizy wiedzy obiektywnej, przeł. D. Leszczyński, Gdańsk 2002, s. 19.

${ }^{43}$ Idem, Le monde comme caprice et miniature, „Recherches Philosophiques” 19331934, vol. 3, s. 306-320.

44 Por. ,[...] le psychisme est animé d'une véritable faim d'images”. G. Bachelard, La terre et les rêveries de la volonté, Paris 1948, s. 26 [podkr. - G.B.].

45 J. Błoński, Przedmowa [w:] G. Bachelard, Wyobraźnia poetycka, s. 15.

${ }^{46}$ M. Popiel, Estetyka kaprysu. W kręgu wizualizacji, ,Teksty Drugie”2009, nr 1-2, s. 103.

${ }^{47}$ B. Schulz, Manekiny [w:] idem, Opowiadania..., s. 32. 
[...] laseczkę spacerowicza, [...] [którą - dop. M.P.] grzebie melancholijnie [...] w gruzie: problemy i problemy, szczątki, ułamki i fragmenty problemów. Tu głowa odłamana patrzy z ukosa, tam noga wygrzebuje się, gramoli i kuśtyka samotnie przez śmietnisko. Jeszcze jest w tych rudymentach słaby fluid życia, jeszcze zbliżone do siebie łączą się i ożywiają. Wędrowiec lubi je rekonstruować i składać, niekoniecznie właściwą głowę do właściwego tułowia. Tak powstają dziwolągi. Wędrowiec cieszy się i zanosi się cichym śmiechem, gdy te dziwotwory spierają się ze sobą o zamienione głowy. Zaciera ręce, gdy mu się uda wywołać powszechny zamęt, maskaradę nieporozumień, wieżę Babel idei ${ }^{48}$.

Poprzez figurę wieży Babel i starego kuglarza powróćmy do George’a Steinera i jego trzech posępnych błaznów XX-wiecznej awangardy, którzy zamienili świat w jeden ready-made. Czyż Schulzu także nie wyprzedza myśli wielkiego humanisty, pytając o to, skąd ten, który ocalał i trafił do ,świata niepodobnego do świata"49, w to rumowisko problemów,

[...] czerpie tę lekkość, ten humor wisielczy, jak zbył powagi, ciężaru odpowiedzialności i stał się tancerzem dna? [...]

I może dobrze się stało, że wszystko legło w gruzy, że nie ma już żadnych świętości, więzów, praw i dogmatów, że wszystko jest dozwolone i wszystkiego można się spodziewać, że wolno raz według swego kaprysu odbudować się z gruzów według swego widzimisię, według chimery, której się jeszcze nie przeczuwa ${ }^{50}$.

Ile jest w słowach Schulza i Steinera gorzkiej ironii wobec „tancerza dna”, wobec człowieka żonglującego resztkami porzuconymi na śmietniku, a ile nadziei łączą oni z nowym człowiekiem kaprysu - któż to zważy, któż to wie? Kto wie: czy ,poiesis [...] upoważnia do bezrozumnej nadziei”"51?

\section{Bibliografia}

Bachelard G., Ksztattowanie się umystu naukowego. Przyczynek do psychoanalizy wiedzy obiektywnej, przeł. D. Leszczyński, Gdańsk 2002.

Bachelard G., La terre et les rêveries de la volonté, Paris 1948.

Bachelard G., Le monde comme caprice et miniature, „Recherches Philosophiques” 1933-1934, vol. 3.

\footnotetext{
${ }^{48}$ Idem, Wędrówki sceptyka, s. 407-408.

49 Ibidem, s. 409.

${ }^{50}$ Ibidem, s. 409-410.

${ }^{51}$ G. Steiner, op.cit., s. 228.
} 
Bachelard G., Wyobraźnia poetycka. Wybór pism, wyb. H. Chudak, przeł. H. Chudak, A. Tatarkiewicz, przedm. J. Błoński, Warszawa 1975.

Czabanowska-Wróbel A., Obraz Króla Olch w prozie Schulza [w:] Czytanie Schulza. Materiaty międzynarodowej sesji naukowej „Bruno Schulz - w stulecie urodzin i w pięćdziesięciolecie śmierci”, red. J. Jarzębski, Kraków 1994.

Ficowski J., Regiony wielkiej herezji i okolice. Bruno Schulz i jego mitologia, Sejny 2002. Ficowski J., W poszukiwaniu partnera kongenialnego [w:] Czytanie Schulza. Materiały międzynarodowej sesji naukowej „,Bruno Schulz - w stulecie urodzin i w pięćdziesięciolecie śmierci”, red. J. Jarzębski, Kraków 1994.

Gilot F., Lake C., Żyć z Picassem, przeł. M. Iwańska-Feliksowa, Warszawa 1997.

Gombrowicz W., Twórczość Brunona Schulza [w:] idem, Varia, Paryż 1973.

Jarzębski J., Dramat tworzenia [w:] idem, Schulzowskie miejsca i znaki, Gdańsk 2016. Kuczyńska-Koschany K., Rilke poetów polskich, Wrocław 2004.

Markowski M.P., Polska literatura nowoczesna. Leśmian, Schulz, Witkacy, Kraków 2007.

Panofsky E., Perspektywa jako ,forma symboliczna”, przeł. G. Jurkowlaniec, Warszawa 2008.

Popiel M., Estetyka kaprysu. W kręgu wizualizacji, „Teksty Drugie” 2009, nr 1-2.

Popiel M., Historia historii tworzenia [w:] Projekt na daleka metę. Prace ofiarowane Ryszardowi Nyczowi, red. Z. Łapiński, A. Nasiłowska, Warszawa 2016.

Rilke R.M., Auguste Rodin, przeł. Olwid [W. Hulewicz], Warszawa-Kraków 1923.

Rilke R.M., Auguste Rodin, przeł. W. Wirpsza, Kraków 1963.

Rilke R.M., Druga strona natury. Eseje, listy i pisma o sztuce, przeł. i oprac. T. Ososiński, Warszawa 2010.

Sandauer A., Rilke, „Polityka” 1982, nr 33.

Schulz B., Księga listów, zebrał i przygot. do druku J. Ficowski, uzup. S. Danecki, Gdańsk 2016.

Schulz B., Opowiadania. Wybór esejów i listów, oprac. J. Jarzębski, Wrocław 1989.

Schulz B., Z listów odnalezionych, wstęp i oprac. J. Ficowski, Warszawa 1993.

Stala K., Architektura Schulzowskiej wyobraźni [w:] Czytanie Schulza. Materiały międzynarodowej sesji naukowej „Bruno Schulz - w stulecie urodzin i w pięćdziesięciolecie śmierci”, red. J. Jarzębski, Kraków 1994.

Stala K., Na marginesach rzeczywistości. O paradoksach przedstawiania w twórczości Brunona Schulza, Warszawa 1995.

Steiner G., Gramatyki tworzenia. Na podstawie wygłoszonych w roku 1990 wykładów imienia Gifforda, przeł. J. Łoziński, Poznań 1991.

Valéry P., Choses tues [w:] idem, Oeuvres, édition par J. Hytier, vol. 2, Paris 1960.

Winwar F., Wingless Victory: A Biography of Gabriele D'Annunzio and Eleonora Duse, New York 1956. 